RAFAŁ RIEDEL

Uniwersytet Opolski

DOI : $10.14746 /$ rie.2016.10.3

\title{
Ekonomia polityczna jako interdyscyplinarne podejście do studiów nad integracją europejską
}

\section{Wprowadzenie}

W Polsce, podobnie jak w całym świecie post-komunistycznym, pojęcie ekonomii politycznej budzi negatywne skojarzenia, głównie ze względu na utożsamienie jej z pewnymi elementami marksizmu. Myśliciele ekonomii socjalistycznej wielokrotnie odwoływali się do tego pojęcia, często go nadużywając czy nadinterpretowując (proletariacka versus burżuazyjna ekonomia polityczna). W konsekwencji wraz z bankructwem socjalistycznych koncepcji budowy gospodarki i społeczeństwa, deprecjacji uległo samo pojęcie ekonomii politycznej. Jednak współcześnie obserwujemy jego renesans - wzajemne relacje polityki i gospodarki zajmują uwagę badaczy w coraz większym stopniu. Jednocześnie, należy zauważyć, są to badania nieobciążone balastem złej reputacji pochodzącej z czasów sprzed 1989 roku.

Warto zatem wykorzystać dorobek autorów wpisujących się w nurt ekonomii politycznej do lepszego zrozumienia procesów, zjawisk i mechanizmów integracji międzynarodowej. Na gruncie nauk politycznych systematycznie ignoruje się dorobek ekonomicznych sposobów teoretyzowania integracji międzynarodowej (podobnie zresztą jak ekonomiści ignorują dorobek politologów w tym zakresie), co wydaje się oczywistym błędem. Optymalna sytuacja to sytuacja dialogu pomiędzy obydwoma dyscyplinami, które z różnych perspektyw opisują te same zjawiska.

Niniejszy tekst rozpoczyna zdefiniowanie czym właściwie jest ekonomia polityczna i jak należy rozumieć to podejście badawcze. Następnie autor dokonuje krótkiego przeglądu rozwoju myśli ekonomii politycznej od Antoine de Montchrestiena i jego pracy z początków XVIII wieku, aż do Thmoassa Piktty’ego i jego głośnej publikacji wydanej w Polsce w 2015 roku. Kolejna część to syntetyczne odniesienie się do głównych nurtów ekonomicznych sposobów teoretyzowania procesów integracyjnych, które pozwala nieekonomicznej części czytelników zapoznać się w przystępny sposób z głównym dorobkiem ekonomii w tym zakresie.

\section{Ekonomia polityczna - zarys i ewolucja}

Za twórcę pojęcia ekonomii politycznej uważa się francuskiego ekonomistę Antoine de Montchrestien, autora pracy pt. Traktat o ekonomii politycznej z 1615 roku (de Montchrestien, 1615). W najbardziej ogólnym sensie, ekonomia polityczna jest nauką, która bada społeczny proces produkcji, jej celem jest wykrycie praw rządzących tym procesem (Sadzikowski, 1981, s. 13). Zajmuje się więc badaniem praw rządzą- 
cych procesami produkcji, podziału i wymiany środków służących do zaspokojenia ludzkich potrzeb.

Jedną z najbardziej wyraźnie wyartykułowanych definicji ekonomii politycznej zawiera praca Kapitat w XXI wieku Thomasa Piketty'ego, który przypisuje jej następujący cel: ,,[...] ekonomia polityczna zmierza do naukowego, a w każdym razie racjonalnego, w sposób systematyczny i metodyczny, badania tego jaka powinna być idealna rola państwa, a także jakie instytucje i polityki publiczne najbliższe są idealnemu społeczeństwu" (Piketty, 2015, s. 726).

Klasyczna ekonomia polityczna rozwinęła się w XVIII i XIX wieku w Wielkiej Brytanii, Francji i Niemczech. Problem podziału dóbr znajduje się w centrum jej analiz. Niewątpliwie związane było to z zachodzącymi wówczas procesami gospodarczymi i społecznymi. Radykalne przekształcenia, które wówczas miały miejsce to rewolucja przemysłowa, migracje ze wsi do miast oraz wzrost demograficzny. Dlatego też klasycznych myślicieli tego okresu zajmowały przede wszystkim takie pytania jak: jakie będą konsekwencje tych przemian dla podziału dóbr, struktury społecznej i równowagi politycznej (Piketty, 2015, s. 14)?

Thomas Malthus dostrzega problem głównie w przeludnieniu (Malthus, 1798). Obserwując eksplozję demograficzną Francji i towarzyszącą jej biedę, formułuje swoje ostrzeżenia przed nędza, chaosem i zaburzeniami porządku społecznego dla Anglii. David Ricardo z kolei koncentruje się na długookresowym wzroście ceny ziemi i poziomu renty gruntowej (Ricardo, 1817). Nawiązując do Malthusa i jego troski w sprawie zagrożeń demograficznych, Ricardo prognozuje, że w związku z przyrostem ludności, zasób taki jak ziemia, będzie zasobem coraz rzadszym (teza o rzadkości występowania dóbr). W konsekwencji, zgodnie z zasadami podaży i popytu, jej cena - podobnie jak poziom renty z tytułu jej dzierżawy - będzie stale rosła, przyczyniając się w ten sposób do jeszcze większych nierówności społecznych. Sytuacja taka faworyzuje bowiem dotychczasowych właścicieli ziemskich. O ile w czasach Ricardo ta przepowiednia wydawała się spełniać, z perspektywy czasu wiemy, że ostatecznie się jednak nie potwierdziła. Cena renty gruntowej i ziemi rolnej ostatecznie spadła, wobec rosnącej istotności innych dóbr, związanych z przekształceniami tej fazy kapitalizmu i systematycznym odchodzeniu od rolnictwa, tudzież spadku udziału rolnictwa w dochodzie narodowym.

Kolejny ważny myśliciel tej epoki to Karol Marks. W swoim wiekopomnym dziele Kapitat (Marks, 1867) próbuje on całościowo spojrzeć na dynamikę kapitalizmu przemysłowego XIX-wiecznej Europy. Główną troską Marksa jest nędza proletariatu przemysłowego. Nawiązuje do niej już w swoim wcześniejszym tekście Manifest partii komunistycznej (Marks, 1848), w którym zapowiada transformację systemu na miarę rewolucji. Przewiduje więc upadek kapitalizmu i generalnie wszystkie jego dzieła, to naukowa próba zrozumienia i wyjaśnienia jego przyczyn, jak i skutków. O ile myśl ta została podchwycona i zinstrumentalizowana dla celów politycznych, najpierw przez bolszewików, a następnie przez inne reżimy bloku wschodniego po drugiej wojnie światowej, o tyle na zachodzie Europy ta apokaliptyczna wizja nie ziściła się i kapitalizm miał się dobrze. Co więcej, XX wiek to również czas bardziej optymistycznych interpretacji ewolucji kapitalizmu. Wystarczy wspomnieć Simona Kuznetsa, który przewidywał, że nierówności będą się w kolejnych fazach kapitalizmu spontanicznie 
i systematycznie zmniejszać (Kuznets, 1955, s. 1-28). Dzisiejsza perspektywa czasowa pozwala nam zweryfikować zarówno tezy Marksa, jak i Kuznetsa. Do rewolucji proletariatu rzeczywiście doszło, co ustanowiło porządek społeczno-gospodarczy w znacznej części Europy i świata przez około sześć, siedem dekad. Ostatecznie jednak praktyczna aplikacja myśli marksistowskiej zakończyła się spektakularną klęską (implozja gospodarki Związku Radzieckiego i rozpad bloku wschodniego). Teoria Kuznetsa z kolei nie wytrzymała konfrontacji z faktami ekonomicznymi w drugiej połowie XX wieku, kiedy to proces akumulacji i podziału kapitału, prowadził ostatecznie do rosnącej dywergencji majątków.

Również Polacy zapisali się w rozwoju tej dyscypliny. Julian Dunajewski, prawnik, ekonomista, wykładowca i rektor Uniwersytetu Jagiellońskiego, jeden z najwybitniejszych myślicieli końca XIX wieku, został zapamiętany głównie jako orędownik wolności gospodarczej. Na gruncie ekonomii politycznej odwoływał się on głównie do postulatu decentralizacji państwa (krytykując centralizm ówczesnych Prus).

Wracając jednak do najbardziej współczesnej pracy poświęconej ekonomii politycznej Kapitał w XXI wieku, należy zauważyć, że Thomas Piketty skupia się w swojej książce przede wszystkim na nierównościach, jednak przekaz tej publikacji jest zdecydowanie szerszy. Stanowi ona pełny przegląd sposobów dystrybucji bogactwa w perspektywie porównawczej zarówno w ujęciu historycznym, jak i pomiędzy poszczególnymi państwami i ich gospodarkami. Analiza obejmuje historyczną rekonstrukcję rozwoju kapitału (i kapitalizmu) oraz ewolucji nierówności dochodowych sięgającą początków ery przemysłowej. Równolegle Piketty rekonstruuje również myśli kluczowych myślicieli danej epoki, którzy na bieżąco interpretowali rozwój gospodarczy. Odwołuje się przede wszystkim do okresu przełomu XVIII i XIX wieku. Thomas Pikettty wchodzi w dyskurs m.in. z Thomasem Malthusem, Davidem Ricardo i, oczywiście, Karolem Marksem. Pozwala mu to zrozumieć dynamikę kapitalizmu przemysłowego w pełnym rozkwicie, jednocześnie pozwala mu to również odnosić współczesne obserwacje do teorii pozostawionych przez XIX-wiecznych myślicieli.

Najważniejszy argument Thomasa Piketty'ego sprowadza się do stwierdzenia, że głównym źródłem nierówności jest kumulacja kapitału. Stopa zwrotu z kapitału przewyższa bowiem - w długim horyzoncie czasowym - stopę wzrostu gospodarczego, a zatem przychody z pracy, skorelowane ze zmienną wzrostu gospodarczego, są w mniejszym stopniu źródłem nierówności społecznych. Dotyczy to zarówno nierówności w ramach danego systemu gospodarczego (np. państwa), jak i w skali międzynarodowej.

Właśnie relacja pomiędzy zwrotem z kapitału a wzrostem gospodarczym stanowi punkt ciężkości i główną oś analizy Thomasa Piketty’ego. Ta zbieżność usprawiedliwia również podobieństwa do dziewiętnastowiecznej publikacji Kapitał Karola Marksa. Nie tylko tytuł, ale sama ranga problemu i waga publikacji czynią porównania z dziełem niemieckiego ekonomisty adekwatnymi. Podobnie jak Marks, Piketty podchodzi nieufnie do wszelkiego determinizmu ekonomicznego: ,[...] historia podziału bogactw jest zawsze historią głęboko polityczną i nie może być sprowadzona do mechanizmów czysto ekonomicznych" (Piketty, 2015, s. 35). Co więcej, Autor Kapitału w XXI wieku uważa, że redukcja nierówności widoczna w latach 1900-1910 czy 1950-1960 była związana z konfliktami wojennymi i ich polityczno-ekonomicznymi skutkami. Z kolei 
radykalny wzrost nierówności, obserwowany od lat 1970. spowodowany jest głównie prowadzoną polityką fiskalną. Kolejny ważny wniosek Thomasa Piketty'ego stanowi, iż dynamika podziału bogactw uruchamia potężne mechanizmy popychające na przemian, bądź w kierunku konwergencji, bądź zróżnicowania, i że nie istnieje żaden naturalny proces, który pozwalałby na uniknięcie destabilizujących i sprzyjających nierównościom tendencji w sposób trwały.

Kapital w XXI wieku, Thomasa Piketty'ego dotyka w konsekwencji wielu aktualnych problemów współczesnego kapitalizmu. Szczególnie aktualne wydają się rozważania dotykające problematyki zadłużenia publicznego. W wielu punktach Piketty pozwala sobie na dość ryzykowne sądy, np. iż od początku ery przemysłowej permanentnie jedna część społeczeństwa zadłużona jest dożywotnio u drugiej części społeczeństwa. Dług publiczny to w zasadzie wierzytelność jednej części kraju (tych, którzy płacą odsetki), na rzecz innej części kraju (tych którzy otrzymują odsetki).

Ostatecznie, najważniejszy wniosek z analizy Thomasa Piketty'ego to stwierdzenie, iż , $[. .$.$] gospodarka rynkowa oparta na własności prywatnej, pozostawiona sama$ sobie, zawiera ważne siły konwergencji związane zwłaszcza z upowszechnieniem wiedzy i kwalifikacji, ale również siły rozwarstwienia, potężne i potencjalnie zagrażające naszym demokratycznym społeczeństwom oraz wartościom sprawiedliwości społecznej, na których się one opierają" (Piketty, 2015, s. 723).

Interesujące są te punkty myśli Piketty'ego, które dotyczą dywergencji i konwergencji pomiędzy poszczególnymi krajami - dotykają one bowiem problematyki międzynarodowej integracji gospodarczej, tak istotnej z perspektywy europejskiej. Thomas Piketty, odpowiadając na pytanie jakie siły pozwalają na konwergencję pomiędzy krajami, sugeruje: „W zasadzie mechanizm, za pomocą którego bogate kraje wchodzą w posiadanie części krajów biednych może mieć dobre skutki w zakresie konwergencji. Jeśli zamożne kraje mają taki nadmiar oszczędności i kapitału, że [...] jego "produktywność końcowa« jest bardzo słaba, wówczas może okazać się korzystne dla wszystkich, by poszły one inwestować część swoich oszczędności w krajach biednych. W ten sposób kraje bogate - albo przynajmniej te z nich, które dysponują kapitałem - uzyskują lepszą stopę zwrotu dla swojej lokaty kapitału, natomiast kraje biedne będą mogły szybciej nadrobić opóźnienie w produktywności" (Piketty, 2015, s. 92). Powyższy opis wydaje się trafnie charakteryzować ostatnią dekadę (a nawet ćwierćwiecze) integracji europejskiej z udziałem gospodarek post-komunistycznych, kiedy to inwestycyjne transfery kapitału w kierunku wschodnim motywowane poszukiwaniem wyższej stopy zwrotu, niosły ze sobą również skutek transferu myśli technologicznej, wzrostu efektywności i wyrównywania poziomu rozwoju społeczno-gospodarczego na niespotykaną w historii skalę.

Po raz kolejny autor odnosi się do kwestii europejskich w końcowych rozważaniach (podrozdziały: ,Euro” pieniadz bez państwa na XXI wiek?, Kwestia zjednoczenia europejskiego), sugerując połączenie długów publicznych strefy euro. $\mathrm{Z}$ akceptacją odnosi się do niemieckiego pomysłu „funduszu odkupienia” i generalnie jego poglądy na temat integracji europejskiej można określić jako federalistyczne. Piketty postuluje utworzenie parlamentu budżetowego strefy euro, upolitycznienie procesu integracyjnego, upowszechnienie podejmowania decyzji zwykłą większością głosów czy prowadzenie polityki fiskalnej na poziomie ponadnarodowym. 
T. Piketty, w swojej książce Kapitał w XXI wieku konfrontuje swoje badania z neoklasycznym modelem wzrostu gospodarczego. Podsumowuje aktualny stan wiedzy na temat podziału dochodu i majątków (począwszy od XVIII wieku) i wysuwa z tego wnioski dla XXI-wiecznego kapitalizmu. Stopa zwrotu z kapitału była, jest i najprawdopodobniej będzie znacząco wyższa, niż stopa zwrotu z dochodu i produkcji. Nierówność ta sprawia, że majątki zgromadzone w przeszłości re-kapitalizują się szybciej (niż tempo wzrostu płac). Mechanizm ten jest głównym źródłem rozwarstwienia, które zagraża - zdaniem Piketty’ego - nie tylko wartościom sprawiedliwości społecznej, ale wręcz demokratycznym społeczeństwom. Panaceum na ten problem, zaproponowanym przez autora, jest progresywny (doroczny) podatek od kapitału. Piketty ma świadomość, że nie jest to rozwiązanie, które może być wprowadzone na poziomie krajowym. Wymagałoby ono szerokiego porozumienia właściwie w skali globalnej.

\section{Integracja gospodarcza w perspektywie ekonomii politycznej}

W relacji do powyższych rozważań, należy odnieść się do głównych definicji integracji gospodarczej, zawierających w sobie elementy leżące w polu zainteresowania ekonomii politycznej. W najprostszym ujęciu, odnoszącym się do etymologii samego słowa ,integracja”, to łączenie się dwóch lub więcej jednostek gospodarczych w większą całość. W literaturze ekonomicznej integracja może więc dotyczyć nawet sytuacji, kiedy mniejsza firma zostaje wchłonięta przez większy koncern. Jednak w niniejszym opracowaniu uwaga skoncentrowana jest zdecydowanie na poziomie międzynarodowych stosunków gospodarczych.

Integracja jest pojęciem wielowymiarowym i wieloaspektowym, stąd mnogość występujących w literaturze definicji tego zjawiska. Pojęcie integracji występowało w literaturze w wielu znaczeniach i ujęciach od dawien dawna (Czarczyńska, Śledziewska, 2000). Co logiczne, w realnym świecie, jako praktyka życia społecznego i gospodarczego chronologicznie wcześniej. Integracja rozumiana jako scalanie postępowała właściwie już od chwili powstania gospodarki towarowej, kiedy to rozpoczęło się łączenie różnych dziedzin działalności gospodarczej (Kamecki, 1967, s. 79). Scalanie takie, obejmując coraz większą przestrzeń geograficzną doprowadziło ostatecznie do powstania nie tylko gospodarek narodowych, ale - w najszerszej skali - gospodarki światowej.

Na uwagę zasługuje fakt, że w żadnym innym obszarze nie mamy do czynienia z tak silnym zintegrowaniem komponentów politycznych z ekonomicznymi. Definicje integracji - zarówno te z literatury ekonomicznej, jak i politologicznej - obejmują takie elementy jak gospodarka, struktury produkcji, państwo narodowe, granice, niepodległość, suwerenność, wzrost konkurencyjności (Ładyka, 2000). Podobnie ma się rzecz, kiedy identyfikujemy cele integracji - najczęściej podejmowane w literaturze to:

- dobrobyt ekonomiczny (prosperity podmiotów uczestniczących wzmaga się dzięki specjalizacji produkcji i koordynowaniu polityk gospodarczych), rozumiany również często jako wzrost efektywności gospodarowania (rozwój gospodarczy, którego syntetycznym miernikiem jest wzrost Produktu Krajowego Brutto); 
- pokój (jeden z głównych powodów integracji gospodarczej w powojennej Europie - zakwestionowanie sensu wzajemnej inwazji poprzez zacieśnienie współpracy gospodarczej);

- demokracja (jeden z warunków uznania za państwo członkowskie, to funkcjonująca demokracja, ze stabilnymi instytucjami gwarantującymi zapewnienie jakościowych standardów demokracji);

- prawa człowieka (warunek wstępny uczestnictwa w układzie integracyjnym) (Molle, 1995, s. 8).

Ze względu na fakt, iż rozwój międzynarodowych stosunków gospodarczych, jako dyscypliny wiedzy, przypadł na okres dominacji państwa narodowego (jako uczestnika stosunków międzynarodowych), większość definicji integracji gospodarczej formułowanych jest z perspektywy państwowo-centrycznej. Tak jest m.in. w przypadku klasycznej definicji W. Roepkego, opartej na tradycyjnej doktrynie wolnego handlu, która konceptualizuje integrację jako stan rzeczy, który umożliwia stosunki handlowe między różnymi gospodarkami narodowymi równie swobodnie i równie korzystnie ${ }^{1}$, jak te, które istnieją wewnątrz gospodarki narodowej (Roepke, 1995). W podobnym duchu definiuje integrację Willem Molle, rozumiejąc ją jednakowoż nie jako pewien stan, ale bardziej jako proces stopniowej eliminacji granic ekonomicznych pomiędzy niepodległymi państwami, w wyniku czego gospodarki tych państw zaczynają funkcjonować jako jedna całość (Molle, 1995, s. 8). Podejście takie odpowiada dominującemu we współczesnych naukach społecznych trendowi sprowadzającemu się do koncentrowania się na dynamicznym charakterze życia społecznego i gospodarczego. Podejścia statyczne stępują podejściom procesowym w prowadzonej analizie naukowej, co wydaje się bardziej adekwatne z punktu widzenia ewolucji samego obiektu badań, jakim jest zjawisko integracji.

W konsekwencji, adekwatne jest również postrzeganie integracji jako procesu powstawania organizmu gospodarczego obejmującego grupe gospodarek narodowych, które - ze względu na powiązania ekonomiczne - wyodrębniają się z systemu gospodarki światowej. Nie są więc one prostą sumą gospodarek składowych, ale tworzą przetworzoną wewnętrznie, spójną całość gospodarczą. Idąc dalej, można poprzez międzynarodową integrację gospodarczą rozumieć proces wewnętrznych i wzajemnych dostosowań struktur gospodarczych łączących się krajów, powstawania strukturalnych powiązań ekonomicznych między krajami, a w konsekwencji spajania ich w jedną całość stanowiącą możliwie jednolity mechanizm gospodarczy, dzięki czemu możliwy jest wzrost konkurencyjności tychże państw w skali międzynarodowej. Wracając do bardziej statycznych ujęć definicyjnych, integracja może więc być również rozumiana - wobec powyższych konceptualizacji - jako dynamiczny układ powiązań gospodarczych pomiędzy krajami, umożliwiający każdemu z nich jak największy poziom rozwoju społeczno-gospodarczego.

W tym duchu formułuje swoją definicję A. Marchal, według którego integracja odpowiada idei solidarności istniejącej między krajami wymieniającymi swoje dobra. Integracja ma miejsce wówczas, kiedy więzi solidarnościowe powoduja, że liberalizacja handlu jest dla wszystkich uczestniczących stron korzystna (Marchal, 1964). To

${ }^{1}$ Proces integracji jest więc tutaj utożsamiany z liberalizacją handlu i płatności. 
ujęcie ewidentnie formułowane jest na podstawie swego rodzaju sądów postulatywnych i odnosi się do idei i pożądanych zasad procesu integracyjnego. Jest to zrozumiałe z punktu widzenia momentu czasowego, kiedy te definicje były formułowane (lata sześćdziesiąte XX wieku), kiedy to proces integracyjny w Europie dopiero nabierał tempa i obserwatorzy tego zjawiska koncentrowali się na wypracowywaniu jego optymalnych uwarunkowań.

Kolejna kwestia zajmująca uwagę teoretyków integracji gospodarczej to sformułowanie zasad integracji ponadnarodowej. Obserwowano bowiem, że bez znaczącej mobilności czynników produkcji, wszelkie międzynarodowe formy integracji okazywały się mało skuteczne i nie przynosiły satysfakcjonujących efektów. Tak więc obok koncepcji strefy wolnego handlu i unii celnej, opartych na powiązaniach horyzontalnych (wymiana dóbr i usług gotowych, bez swobody przepływu czynników produkcji), powstały koncepcje wspólnego rynku, unii ekonomicznej, monetarnej, fiskalnej, wreszcie unii politycznej i pełnej integracji gospodarczej bazujące na przepływie czynników produkcji.

W takiej sytuacji jednakowoż, nieodzowne okazało się zastąpienie koncepcji integracji międzynarodowej (międzyrządowej) formą ponadnarodową. Koncepcja pełnej integracji gospodarczej oznacza bowiem wprowadzenie jednego (w skali ugrupowania) mechanizmu ekonomicznego wykorzystującego wspólny pieniądz (politykę monetarną), zbliżone i skoordynowane zasady utrzymywania równowagi makroekonomicznej.

Jak na razie integracja europejska na kontynencie europejskim realizuje się poprzez koncepcję wspólnego rynku (swobodny przepływ towarów, usług, kapitału i ludzi), unii walutowej (unia monetarna) i skoordynowanej polityki ekonomicznej (unia ekonomiczna). Generalnie wyróżnić można następujące mechanizmy międzynarodowej integracji gospodarczej:

- mechanizm rynku i konkurencji,

- mechanizm regulacyjny,

- mechanizm redystrybucyjny,

- mechanizm planowania.

W pracy wydanej jeszcze w czasach ancient regime'u (1981), Wiesław Sadzikowski zauważa, że pełna integracja prowadziłaby do osłabienia roli państwa (polityk państwowych). Wykluczyłoby to możliwość stosowania przez rządy różnego rodzaju instrumentów i narzędzi politycznych, czyli w konsekwencji skutecznego realizowania polityki gospodarczej. Ujednolicenie warunków prowadzenia działalności gospodarczej ogranicza swobodę rządów w manipulowaniu narzędziami finansowo-podatkowymi, budżetowymi, a nawet często administracyjnymi. Co interesujące, autor dokonuje wykładni swoich argumentów w duchu dominującej wówczas ideologii marksistowskiej, w związku z czym prowadzi go to do wniosku, iż ujednolicenie to może być traktowane jako osłabienie ochrony interesów rodzimej burżuazji (Sadzikowski, 1981, s. 418). Stąd wniosek o ostrożnym, czy nawet sceptycznym podchodzeniu do kolejnych etapów integracji przez elity rządzące państw członkowskich.

Nie zmienia to jednak faktu, że w publikacji tej znajdziemy jedną z bardziej udanych definicji integracji gospodarczej. Wg autora, ma ona na celu przełamanie barier wzrostu gospodarczego, wynikających ze szczupłości rynku wewnętrznego państwa 
narodowego. Procesy integracyjne są skutkiem postępu technologicznego, którego adaptacja, w wielu przypadkach, może być dokonana jedynie w wielkich organizmach gospodarczych, przekraczających rozmiarem pojedyncze gospodarki narodowe (Sadzikowski, 1981, s. 414).

Tworzenie się bloków integracyjnych powoduje ich (częściowe przynajmniej) wyodrębnienie z rynku światowego jako całości. Ujednolicenie zewnętrznej taryfy celnej, przy jednoczesnej likwidacji taryf celnych wewnętrznych powoduje z kolei zmniejszenie się konkurencyjności towarów i usług pochodzenia zewnętrznego. Ten argument ma oczywiście malejące znaczenie w warunkach liberalizacji wymiany handlowej w skali globalnej. Malejące cła w wymianie międzynarodowej czynią taką unię celną mniej efektywną z punktu widzenia zarysowanego powyżej mechanizmu.

Skutki integracji gospodarczej nazywane są w literaturze efektami restrukturyzacyjnymi lub efektami dynamicznymi integracji. Po wyeliminowaniu czynników dyskryminujących swobodną wymianę handlową, obserwujemy wzrost presji konkurencyjnej, która zmusza producentów i usługodawców krajowych do dostosowania relacji cena-jakość do tej obowiązującej w gospodarkach partnerskich. Pierwszą implikacją jest dla nich rezygnacja z renty ekonomicznej w postaci zysków nadzwyczajnych, restrukturyzacja zatrudnienia, kosztów ogólnych. Zwiększona konkurencja prowadzić może również do eliminacji z rynku najmniej efektywnych przedsiębiorstw, fuzji przedsiębiorstw i pojawienie się korzyści wynikających ze skali produkcji (Borowiec, 1997, s. 65).

\section{Ekonomiczne sposoby teoretyzowania integracji międzynarodowej}

Klasycznie, ekonomiczne sposoby teoretyzowania integracji międzynarodowej obejmują następujące elementy:

- Teoria unii celnej i strefy wolnego handlu, w tym:

- statyczna analiza skutków handlowych (efekt kreacji i przesunięcia handlu) - analiza w ramach równowagi cząstkowej i ogólnej,

- dynamiczne skutki utworzenia unii celnej (korzyści skali, wzrost konkurencji i postęp techniczny, zwiększenie efektywności),

- zewnętrzna polityka handlowa (protekcjonizm uwarunkowany), polityka antydumpingowa, antysubwencyjna, klauzule ochronne);

- Teoria wspólnego rynku, w tym:

- tradycyjna (neoklasyczna) analiza przepływu czynników produkcji przy doskonale funkcjonujących rynkach,

- analiza rynku siły roboczej przy niepełnym zatrudnieniu i występowaniu barier w przepływie czynników,

- korzyści z integracji rynków kapitałowych;

- Teorie unii monetarnej - w tym przede wszystkim: teoria optymalnych obszarów walutowych (Balassa, 1961).

Ze względu na obszerny charakter i wysoki stopień jej kontrowersyjności, teorie unii monetarnej nie mogą zostać ujęte w niniejszym artykule - zainteresowanego czytelnika odsyłam do wielu opracowań, które w ostatnim czasie pojawiły się na pol- 
skim rynku wydawniczym. W tym miejscu chciałbym skupić się na dwóch pierwszych punktach, a więc teorii unii celnej oraz teorii wspólnego rynku.

Teoria unii celnej, określana czasami jako teoria integracji rynków produktów jest stosunkowo młodą teorią (Machlub, 1977) i bazuje na teorii handlu międzynarodowego (Greenaway, 1983). Problematyka wolnego handlu zajmowała już klasycznych ekonomistów - za przykład mogą posłużyć rozważania na temat protekcjonizmu Ricardo, czy opis, wyjaśnienie i interpretacje funkcjonowania Niemieckiego Związku Celnego w XIX wieku.

Teoria handlu międzynarodowego odnosi się zazwyczaj do prostego, modelowego przypadku dwóch krajów, które wytwarzają dwa produkty każdy, przy pomocy dwóch czynników produkcji (pracy i kapitału). Punkt wyjścia to sytuacja, w której kraje te stanowią dwie zamknięte gospodarki, a dostępność czynników produkcji jest w nich zróżnicowana, co generuje różnice w kosztach produkcji (teoria kosztów komparatywnych). Po nawiązaniu relacji handlowych sytuacja ulega zmianie - każdy kraj specjalizuje się w produkcji dobra, do którego potrzebny jest najmniejszy relatywnie nakład czynników produkcji. Specjalizacja będzie kontynuowana do czasu, kiedy relacje cenowe w obu krajach staną się identyczne. Oba kraje mogą osiagnąć wzajemne korzyści poprzez specjalizację w produkcji tych dóbr i usług, w których posiadają przewagę (niskie koszty czynników produkcji) oraz ich eksport. Jednocześnie importować mogą te dobra, które z kolei musiałyby produkować po względnie wysokich kosztach, pozostawiając ich produkcję innym gospodarkom. W efekcie taki handel zwiększa dobrobyt i konkurencyjność danej gospodarki (Lindert, 1986). Ekstrapolując można założyć, że wzrost dobrobytu byłby największy w stanie globalnej gospodarki wolnej od ceł, co leży u podstaw paradygmatu o prorozwojowym charakterze polityki liberalizacji wymiany handlowej. Mimo wyraźnego trendu liberalizacyjnego w międzynarodowej wymianie handlowej, większość krajów stosuje różnego rodzaju bariery w postaci ceł, kontyngentów i innych instrumentów. Stanowią one elementy polityki gospodarczej i oddziałują na sferę produkcji oraz strumienie handlu (Molle, 1995, s. 80). Literatura wymienia tutaj trzy modelowe sytuacje, które mogą mieć miejsce w zależności od stopnia restrykcyjności ww. instrumentów:

- autarkię (kiedy producenci z danego kraju zaspokajają w 100\% lokalny popyt i kraj ten pozostaje zamknięty dla rynku światowego - np. poprzez system zakazów importowych lub ceł prohibicyjnych - i w konsekwencji producenci ci pozostaja mniej efektywni, ze względu na brak presji konkurencyjnej z zewnątrz),

- wolny handel (kiedy dany kraj pozostaje otwarty dla rynku międzynarodowego, cena dóbr i usług oferowanych przez lokalnych producentów kształtuje się w okolicach równowagi cenowej),

- protekcjonizm.

W kategoriach ekonomicznych rozwiązaniem preferowanym jest wolny handel. W gospodarce objętej protekcjonizmem, wszelkie dobra produkowane są po koszcie wyższym niż byłoby to konieczne w warunkach wolnego handlu. Konsument płaci za nie więcej, tak więc suma dóbr i usług będących w jego zasięgu (a w konsekwencji i dyspozycji - równowaga podaży i popytu) maleje. Oznacza to ujemny skutek dla popytu wewnętrznego. Popyt zewnętrzny jest z kolei ograniczony ze względu na odwetowe działania partnerów handlowych stosujących zasadę wzajemności. W konse- 
kwencji obserwujemy więc nie tylko obniżenie wolumenów wymiany handlowej, ale spowolnienie gospodarcze w ogóle.

Jednak, mimo, iż klasyczna teoria handlu międzynarodowego sugeruje, iż najlepszym rozwiązaniem jest wolny handel pomiędzy wszystkimi gospodarkami na świecie, postęp w tym zakresie jest zbyt wolny i niektóre kraje próbują przyjąć „następną najlepszą strategię", czyli ograniczoną geograficznie formę wolnego handlu w postaci unii celnej. Unia celna reprezentuje szczególny przypadek (wewnętrznego) wolnego rynku i (zewnętrznego) protekcjonizmu (Molle, 1995, s. 78).

Teoria unii celnej zajmuje się gównie analizą korzyści i kosztów funkcjonowania takich unii. Unie celne nie zawsze kończą się sukcesem i przewagą korzyści nad kosztami. Jednocześnie z politycznego punktu widzenia są one akceptowane tylko wtedy, kiedy jej pozytywne i negatywne konsekwencje są sprawiedliwie rozdzielone pomiędzy jej uczestnikami. W literaturze identyfikuje się pod tym względem trzy możliwe sytuacje:

- kreację handlu (z tą sytuacją mamy do czynienia, kiedy popyt przesuwa się w stronę bardziej efektywnych producentów, jednak całokształt wymiany handlowej rośnie),

- przesunięcie handlu (gdy, wskutek powstania unii celnej, import od producenta spoza jej terytorium zastąpiony zostaje przez producenta $\mathrm{z}$ jednej z gospodarek objętych unią. Wybór danego producenta podyktowany jest jednak taryfami protekcyjnymi wobec świata zewnętrznego, a nie konkurencyjną ofertą z wewnątrz unii celnej),

- ekspansja handlu (taka sytuacja ma miejsce, gdy niska cena rynkowa pobudza popyt krajowy, który zaspokajany jest dzięki handlowi zagranicznemu) (Molle, 1995, s. 87).

Realizacja jednego z powyższych scenariuszy decyduje o sukcesie unii celnej. Jeśli mamy do czynienia z przesunięciem handlu, wtedy producenci zachowują się mniej racjonalnie (co stanowi negatywny aspekt działania unii celnej). Jeżeli jednak mamy do czynienia z kreacją bądź ekspansją handlu, wtedy produkcja danego dobra staje się bardziej efektywna. Oznacza to nie tylko bardziej optymalne zaspokajanie potrzeb konsumentów, ale również uwolnienie części zasobów i umożliwienie realizacji za ich sprawą innych celów gospodarczych.

Dla ostatecznego bilansu korzyści i kosztów funkcjonowania unii celnej ważna jest również struktura produkcji tworzących jej gospodarek. Dwie gospodarki narodowe mogą być względem siebie komplementarne, ale mogą być również konkurencyjne. W sytuacji komplementarności, efekt unii celnej paradoksalnie wcale nie musi być korzystny, ze względu na fakt, że kraje te najprawdopodobniej wyspecjalizowały się również bez istnienia unii celnej. W przypadku konkurowania ze sobą poszczególnych gospodarek, sektorów przemysłowych czy poszczególnych przedsiębiorstw, spodziewane korzyści z funkcjonowania unii celnej będą relatywnie większe. Wymusi bowiem ona, poprzez zwiększoną presję konkurencyjna, większą specjalizację dostawców produktów i usług (Viner, 1950).

Ponadto rozmiar unii celnej ma znaczenie (efekt skali). Tzn. im więcej (większych) gospodarek bierze w niej udział, tym lepiej dla perspektyw podziału pracy (specjalizacji siły roboczej) i mniejsze ryzyko przesunięcia handlu (Mead, 1955). Im większe były taryfy wyjściowe, tym większa korzyść z ich eliminacji. Ta relacyjna zależność 
dotyczy również poziomu taryf celnych z innymi partnerami spoza unii celnej. Będzie ona tym mniej skuteczna, im mniejszy będzie poziom taryf w jej otoczeniu.

Kolejny czynnik warunkujący bilans korzyści i kosztów z unii celnej dotyczy kwestii infrastrukturalnych (Ballasa, 1961). Uwarunkowania geograficzne czy rozwinięta sieć transportowa mają znaczący wpływ na fizyczną realizację transakcji handlowych, dlatego unia celna najprawdopodobniej będzie bardziej udana, jeśli zawierana jest w gronie sąsiadów, z rozbudowaną siecią infrastrukturalną.

W tym miejscu należy również zwrócić uwagę na bardzo ważny czynnik natury politycznej, tzn. wola do prowadzenia pro-integracyjnych polityk gospodarczych i społecznych (Borowiec, Wilk, 1997, s. 14; Lis, Miklaszewski, 1990). Jeśli prowadzi ona do ułatwień w zakresie wymiany produktów i usług, wtedy sukces unii celnej jest bardziej prawdopodobny. Jeśli natomiast w integrujących się gospodarkach stosowane są różnego rodzaju pozataryfowe bariery (natury administracyjnej lub innej), dyskryminujące swobodną wymianę handlową, taka unia celna nie ma szansy na realizację.

Wreszcie ostatnia kwestia warunkująca skuteczność funkcjonowania unii celnej to elastyczność. Im dane, integrujące się, gospodarki mogą reagować bardziej elastycznie na pojawiające się nowe perspektywy i możliwości, tym korzyści są większe. Z kolei w sytuacji występowania ,wąskich gardeł” produkcyjnych, niemożliwe będzie pełne wykorzystanie korzyści wynikających z rozwiniętej specjalizacji i dokonanie korespondującej z nią realokacji produkcji (Molle, 1995, s. 94).

Z kolei teoria wspólnego rynku dostarcza nam wiedzy na temat mechanizmów bardziej zaawansowanej integracji gospodarczej. Stadium wspólnego rynku uznaje się za osiagnięte w sytuacji, w której usunięte zostają nie tylko przeszkody swobodnego przepływu dóbr i usług, ale i czynników produkcji. Wśród motywacji dążeń do utworzenia wspólnego rynku jedną z najważniejszych jest założenie, iż swoboda przepływu kapitału i pracy z dziedzin o niskim produkcie końcowym do tych, w których jest on wyższy, doprowadzi do bardziej efektywnej alokacji (Molle, 1995, s. 154). Sytuacja przedstawia się jednak odmiennie w przypadku siły roboczej oraz kapitału.

W dwóch gospodarkach, które tworzą wspólny rynek, migracja siły roboczej w dłuższej perspektywie będzie prowadziła do konwergencji płac. Ze względów pozaekonomicznych (np. psychologicznych i kulturowych kosztów migracji), nie należy spodziewać się całkowitego wyrównania płac. Aczkolwiek dwa mechanizmy stanowią o sile tej tendencji - po pierwsze napływ taniej siły roboczej stanowi presję na lokalny rynek pracy, ograniczający wzrost płac (a w skrajnych przypadkach nawet ich spadek) na rynkach o pierwotnie wyższych płacach. Jednocześnie odpływ siły roboczej z gospodarek o niższych płacach pierwotnych powoduje zmniejszoną podaż pracy, co jest naturalnym stymulatorem wzrostu płac. Należy zauważyć, że w obliczu tych dwóch mechanizmów, ruchy płacowe oderwane są od kryterium efektywnościowego - tzn. wzrost lub spadek płac optymalnie skorelowany powinien być ze zmianami produktywności.

W związku z powyższym struktura korzyści i kosztów jest bardzo skomplikowana i nie może być ujęta dwuwymiarowo. Z perspektywy pracobiorców w kraju przyjmującym migrantów jest to sytuacja niekorzystna (stąd częste protesty związków zawodowych wobec liberalnej polityki migracyjnej). Pracodawcy z kolei będą zadowoleni w związku ze słabą presją płacową. Jednocześnie w kraju wysyłającym migrantów pracodawcy będą mniej zadowoleni, ze względu na zmniejszającą się podaż pracy (ko- 
rygowaną zwiększającą się ceną). Jednocześnie dla pracobiorców będzie to okoliczność korzystna, ze względu na zwiększający się popyt na pracę w danej gospodarce.

$\mathrm{Z}$ kolei liberalizacja przepływu kapitału spowoduje jego transfer do gospodarki, w której spodziewana stopa zwrotu z inwestycji jest większa. Przy założeniu tego samego ryzyka dla krajowych i zagranicznych inwestycji (temu służyć ma z kolei jednolity reżim prawny na terytorium wspólnego rynku), sytuacja taka wywoła najprawdopodobniej presję na wzrost oprocentowania, czyli mniejszą podaż kapitału w jednej gospodarce kraju przyjmującego bezpośrednią inwestycję zagraniczną, jak również presję na obniżenie oprocentowania (większa podaż kapitału) w gospodarce o spodziewanej niższej stopie zwrotu. Ostatecznie, w długookresowej perspektywie czasowej powinno prowadzić to do wyrównywania się poziomów stóp procentowych, czyli równowagi popytowo-podażowej kapitału².

Nawet jeśli między dwoma krajami nie występowałyby żadne różnice cen czynników produkcji, to usunięcie barier w ich przepływie powinno przyczynić się do lepszej alokacji zasobów (Molle, 1995, s. 154). Teoria ekonomicznej integracji rynków sugeruje, że liberalizacja przepływu czynników produkcji prowadzi ostatecznie do wzrostu dobrobytu. Jednak różnice pomiędzy dochodem z pracy a dochodem z kapitału powodują zróżnicowaną alokację korzyści i kosztów takiej integracji. Dodatkowo transgraniczne przepływy czynników produkcji generują cały zestaw korzyści i kosztów pośrednich, których dystrybucja również jest bardzo zróżnicowana i skomplikowana. Dotyczy to chociażby procesów migracyjnych i związanych z nimi problemów drenażu mózgów, kosztów edukacji, systemów zabezpieczenia emerytalnego itd.

Współzależności pomiędzy rynkami dóbr i rynkami czynników produkcji to kolejny ważny temat, który zajmuje uwagę badaczy. Przy założeniu pełnej mobilności czynników produkcji w ramach wspólnego rynku, spodziewane zyski z handlu skłaniają producentów w każdej ze zintegrowanych gospodarek do przesunięcia zasobów niezbędnych do produkcji do tego kraju, gdzie - ze względu na cenę i dostępność danego czynnika produkcji - są w stanie zbudować swoją przewagę komparatywną.

W efekcie przemieszczenia się czynników produkcji może mieć miejsce przemieszczenie się dóbr, jak również wymiana handlowa implikuje zmiany w zakresie przemieszczania się czynników wytwórczych. Wpływ ten wykracza również poza sam wspólny rynek. Tzn. efekt przesunięcia handlu wywołany utworzeniem unii celnej lub wolnego rynku, może skłonić zagranicznych inwestorów do rozpoczęcia produkcji w ramach unii (,,przeskakiwanie” barier celnych). W takiej sytuacji wzrost inwestycji zagranicznych powiązany jest z jednoczesnym spadkiem importu. Wiąże się to nieuchronnie ze zmianą struktury produkcji zarówno w samej unii, jak i poza nią.

\section{Podsumowanie}

Jednym z najważniejszych wniosków wyrosłych z badań nad unią celną, jest stwierdzenie, że ich funkcjonowanie zmienia strukturę gospodarek w niej uczestniczących (zmienia się w konsekwencji również popyt na czynniki produkcji) (Corden, 1872,

${ }^{2}$ Rodzimy kapitał w kraju o spodziewanej wyższej stopie zwrotu, będzie wyżej oprocentowany, jednocześnie w krajach, gdzie stopa zwrotu jest niższa, będzie niżej oprocentowany. 
s. 465-475). Mamy więc tutaj do czynienia z siłami, które pozostają poza zasięgiem polityk gospodarczych państw członkowskich. Ponadto wszelkie powyższe prawidłowości mają miejsce w warunkach teoretycznych, tzn. idealnego rynku. W praktyce prawie zawsze mamy do czynienia z niedoskonałościami rynkowymi, np. z nieuczciwą konkurencją, kartelami, kryzysami zakłócającymi funkcjonowanie unii celnej.

Wzajemne powiązanie przemysłów może prowadzić do pozytywnych efektów w postaci zwiększonej efektywności, chociażby w związku z transferem technologii. Podobnie jak w przypadku rozważań na temat unii celnej, należy zauważyć, iż powyższe wnioski na temat wspólnego rynku odnoszą się do abstrakcyjnej sytuacji pełnego zatrudnienia i zaangażowania kapitału. Nie należy jednak oczekiwać, że założenie to będzie miało swoje odzwierciedlenie w rzeczywistości. Na małych podzielonych rynkach zarówno podaż, jak i popyt na czynniki produkcji, mogą być ograniczone ${ }^{3}-\mathrm{z}$ ujemnymi skutkami zarówno dla produkcji dóbr i usług, jak i dobrobytu (Molle, 1995, s. 160).

Podsumowując, w literaturze ekonomicznej wyróżnia się następujące etapy procesu międzynarodowej integracji gospodarczej:

- stowarzyszenie wolnego handlu (liberalizacja handlu między krajami członkowskimi),

- unię celną (wspólna zewnętrzna taryfa celna),

- wspólny rynek (wolny przepływ czynników produkcji),

- unię ekonomiczną (harmonizacja polityki gospodarczej),

- pełną integrację ekonomiczną (unifikacja polityki ekonomicznej) (Borowiec, Wilk, 1997, s. 23).

Jak więc wynika z powyższego zestawienia etapów integracji gospodarczej, proces ten odbywa się na płaszczyźnie ekonomicznej, jak i na płaszczyźnie politycznej. Perspektywa ekonomii politycznej pozwala nie tylko dostrzec obydwa wymiary, ale dokonać ich symbiozy. Tak jak sam proces integracji europejskiej jest jednocześnie procesem ekonomicznym i politycznym, tak i sposób jego opisywania i teoretyzowania powinien uwzględniać obydwa wymiary.

\section{Bibliografia}

Balassa B. (1961), The theory of economic integration, Irwin, Homewood, Illinois.

Borowiec J., Wilk K. (1997), Teoria i praktyka europejskiej integracji gospodarczej, Wrocław.

Corden W. M. (1972), Economies of scale and customs union theory, ,Journal of Political Economy”, t. 80.1, s. 465-475.

Czarczyńska A., Śledziewska K. (2000), Teoria integracji europejskiej, Gdańsk.

Dunajewski J. (2012), Wykład ekonomii politycznej. Klasyka polskiej myśli wolnorynkowej, Warszawa.

Greenaway D. (1983), International trade policy, from tarrifs to the new protectionism, Macmilan, Londn.

Kamecki Z. (1967), Pojęcia i typy integracji gospodarczej, „Ekonomista”, nr 1.

Kuznets S. (1955), Economic growth and income inequality, „The American Economic Review”, vol. 45 , nr 1, s. 1-28.

${ }^{3}$ Mamy do czynienia z selektywną mobilnością pracy (międzyregionalną, w ramach danej profesji czy segmentu gospodarki). 
Lindert P. (1986), International Economics, Irwin, Homewood, Illinois, 1986.

Lis S., Miklaszewski S. (1990), Procesy międzynarodowej integracji regionalnej, Kraków.

Ładyka S. (2000), Z teorii integracji gospodarczej, Warszawa.

Machlup F. (1977), A History of Thought on Economic Integration, Macmillan, London.

Malthus T. (1798), Prawo ludności, Oxford.

Marks K. (1848), Manifest partii komunistycznej, Londyn.

Marks K. (1867), Kapitat, Hamburg.

Marchal A. (1964), L'Europe Solidaire, Paris.

Mead J. E. (1955), The theory of customs union, Amsterdam.

Molle W. (1995), Ekonomika integracji europejskiej. Teoria, praktyka, polityka, Gdańsk.

Molle W. (2000), Ekonomika integracji europejskiej, Gdańsk.

de Montchrestien A. (1615), Traktat o ekonomii politycznej, Paryż.

Piketty T. (2015), Kapitat w XXI wieku, Warszawa.

Ricardo D. (1817), Zasady ekonomii politycznej i opodatkowania, Londyn.

Roepke W. (1995), International Order and Economic Integration, Dordrecht.

Sadzikowski W. (1981), Ekonomia polityczna kapitalizmu, Warszawa.

Viner J. (1950), The customs union issue, London.

\section{Streszczenie}

Celem niniejszego tekstu jest spojrzenie na studia z zakresu integracji europejskiej z perspektywy ekonomii politycznej. Zabieg taki pozwala na uchwycenie dwóch głównych wymiarów natury Unii Europejskiej, tj. ekonomicznego i politycznego, jak również stymulowania dialogu pomiędzy tymi dwoma sposobami teoretyzowania integracji europejskiej. Niniejszy tekst przybliża zasadniczo ekonomiczny dorobek w zakresie studiów europejskich (w sposób przystępny dla nie-ekonomistów), pozwalając na lepsze zrozumienie procesów, zjawisk i mechanizmów integracji międzynarodowej.

Słowa kluczowe: ekonomia polityczna, integracja europejska, interdyscyplinarność

\section{Political economy as an interdisciplinary approach to European integration studies}

\section{Summary}

The objective of the article is to see the studies on European integration from the perspective of the political economy, which allows to capture the two most important dimensions of the European Union, that is the economic and political one. It also stimulates the dialog between the two ways of theorising the European integration. The proposed text reconstructs the economic discourse in the European studies (in a way which is friendly for non-economists') and helps to better understand the processes, phenomena and mechanics of international integration.

Key words: Political economy, European integration, interdisciplinarity 